\title{
Effects of Probiotics and Wheat Bran Supplementation of Broiler Diets on the Ammonia Emission from Excreta
}

\author{
Nikoletta Such ${ }^{1}$, Gábor Csitári ${ }^{1}{ }^{\circledR}$, Petra Stankovics ${ }^{2}$, László Wágner ${ }^{1}$, Ilona Anna Koltay ${ }^{1}$, Valéria Farkas ${ }^{1}$, \\ László Pál ${ }^{1}$, Patrik Strifler ${ }^{1}$ and Károly Dublecz ${ }^{1, *}$ (1)
}

1 Institute of Physiology and Nutrition, Georgikon Campus, Hungarian University of Agriculture and Life Sciences, Deák Ferenc Street 16, 8360 Keszthely, Hungary; such.nikoletta.amanda@phd.uni-mate.hu (N.S.); csitari.gabor@uni-mate.hu (G.C.); wagner.laszlo@uni-mate.hu (L.W.); ilcsu92@gmail.com (I.A.K.); farkas.valeria@uni-mate.hu (V.F.); pal.laszlo@uni-mate.hu (L.P.); strifler.patrik@phd.uni-mate.hu (P.S.)

2 Institute of Crop Production, Georgikon Campus, Hungarian University of Agriculture and Life Sciences, Deák Ferenc Street 16, 8360 Keszthely, Hungary; stankovics.petra@gmail.com

* Correspondence: Dublecz.Karoly@uni-mate.hu; Tel.: +36-30-6418597

Citation: Such, N.; Csitári, G.; Stankovics, P.; Wágner, L.; Koltay, I.A.; Farkas, V.; Pál, L.; Strifler, P.; Dublecz, K. Effects of Probiotics and Wheat Bran Supplementation of Broiler Diets on the Ammonia Emission from Excreta. Animals 2021, 11, 2703. https://doi.org/10.3390/ani11092703

Academic Editor: Marco Zampiga

Received: 9 August 2021

Accepted: 13 September 2021

Published: 15 September 2021

Publisher's Note: MDPI stays neutral with regard to jurisdictional claims in published maps and institutional affiliations.

Copyright: (c) 2021 by the authors. Licensee MDPI, Basel, Switzerland. This article is an open access article distributed under the terms and conditions of the Creative Commons Attribution (CC BY) license (https:// creativecommons.org/licenses/by/ $4.0 /)$.
Simple Summary: Animal production is the main source of ammonia emission worldwide and all member countries of the European Union must reduce their national emissions. Among nutritional strategies, feeding low protein diets, using more nutritional phases, or using different feed additives can decrease the nitrogen excretion of animals and, in this way, lower the ammonia volatilisation from the manure. Pro- and prebiotics are widely used to improve gut health and to decrease the incidence of diseases. Numerous research findings have been published on the practical effects of pro- and prebiotics, but their impact on the urinary and faecal $\mathrm{N}$ excretion in chickens has not been completely clarified yet. In this research, the effects of using lactic acid and butyric acid producing bacterial strains, and wheat bran as a potential prebiotic, was tested with broiler chickens. Both probiotics increased the dry matter content and decreased the urinary $\mathrm{N}$ ratio of the excreta, which is positive from an ammonia emission point of view. Wheat bran and its xylan-oligosaccharides decreased both the ammonium - $\mathrm{N}$ content and the urinary $\mathrm{N}$ ratio. The results proved that beside the well-known nutritional techniques, the feed additives, which modify the gut microbiota and the fermentation in the caeca, can decrease the urinary- $\mathrm{N}$ excretion, and in this way lower the ammonia emission of broiler chickens.

Abstract: Ammonia emission is a concern for the poultry industry from both environmental and animal welfare points of view. The objective of this research was to determine whether probiotics or wheat bran supplementation of broiler diets can modify the $\mathrm{N}$ composition of the excreta and the dynamics of ammonia volatilisation emission from the manure. A total of 120-day-old Ross 308 broiler chickens were fed six different diets. The treatments included a corn and soybean meal-based control diet $(\mathrm{C})$ and diets containing wheat bran (WB). Both diets were fed alone and with supplementation of a lactic acid (Lactobacillus farciminis, LAB) and a butyric acid (Clostridium butyricum, BAB) producing bacterial strain. Treatment BAB had a significant effect on the dry matter content of the excreta and both probiotics decreased the amount of excreted uric acid. Treatment WB resulted in a significantly lower $\mathrm{NH}^{+}{ }_{4}-\mathrm{N}$ concentration of excreta and a tendency toward reduced uric acid content. Treatment LAB reduced the urinary $\mathrm{N}$ ratio of excreta. Among dietary treatments, WB resulted in the highest urease producing cell numbers in the excreta, but this difference was not significant. Based on our results, similar to pigs, the soluble fibre fraction of poultry diets can also modify the urinary to faecal $\mathrm{N}$ ratio of the excreta.

Keywords: urease activity; ammonia; broiler; nitrogen; wheat bran; Lactobacillus farciminis; Clostridium butyricum 


\section{Introduction}

Antibiotics have been used in animal husbandry as growth promoters for more than 60 years [1]. However, their application has led to the increase in antibiotic-resistant bacteria. This has come to the forefront of attention as a potential source of danger in recent years [2]. The use of antibiotics as a growth promoter was banned in the European Union in 2006, and since then, several alternative feed additives have been tested, including pre- and probiotics [3]. Probiotics are defined by the World Health Organization as "microorganisms" administered in a live form and in adequate amounts to improve the health of the host. Probiotics can kill pathogenic microorganisms with the help of their antimicrobial compounds such as bacteriocins and organic acids. They improve the stability of the gastrointestinal microbial environment, thereby preventing the binding and colonization of pathogens, stimulating intestinal-induced immune responses, improving digestion and absorption of nutrients [4]. Prebiotics are mostly oligosaccharides, supplying nutrients for bacteria considered as favourable [5]. Oligosaccharides form because of fibre degradation and are primary substrates for the growth of intestinal microorganisms [6]. Fermentable oligosaccharides increase the concentration of short chain fatty acids (SCFA) in the cecum and colon, which decrease the $\mathrm{pH}$ and hence the colonisation of the potentially harmful bacteria [7]. Beside the well-known prebiotics such as fructose oligosaccharides and mannan oligosaccharides, the soluble arabinoxylan of wheat also has a prebiotic effect if the diets are supplemented with exogenous xylanase [8]. SCFAs also play an important role as an energy source of the host and the epithelial cells. Acetic acid, propionic acid, butyric acid and lactic acid are also important in the "cross-feeding" mechanism of the different bacterial groups [9]. The more intensive bacterial fermentation increases bacterial biomass, bacterial diversity and hence the excreted microbiota [10]. The non-digestible and unutilized dietary nitrogen excreted via faeces and urine is converted to gaseous ammonia by aerobic or anaerobic bacteria in the manure [11]. Much of the ammonia released from manure comes from the hydrolysis of urea [12], or in the case of birds from the breakdown of uric acid [13].

It is well known that in mammals such as pigs, the urinary $\mathrm{N}$ content can be decreased if fermentable carbohydrates, for example sugar beet pulp, are fed. The increased bacterial biomass can reduce ammonia emission in the intestines, because ammonia formed in the post-small intestinal tract is converted in a greater proportion to bacterial protein [14]. As a result, less ammonia is absorbed from the caeca and recirculated to the liver, which reduces the synthesis of uric acid. Bacterial proteins are excreted via faeces, and the bacteria in the manure are unable to release ammonia from this protein in a short time. Since the fibre fermentation capacity of birds is limited, this mechanism is not yet proved in the case of chickens [15].

Based on the available research results, uric acid represents $50-60 \%$ of the total $\mathrm{N}$ content of poultry excreta [16]. With the development of nutrition and genetics, this ratio may have changed, but only a few results are available concerning this topic in the literature. Ammonia emission is a concern for the poultry industry from both an environmental and animal welfare point of view. Potential effects on birds include respiratory diseases, viral infections, decreased production, and higher mortality [17].

Numerous research findings have been published on the practical effects of probiotics [18], but their impact on the urinary and faecal $\mathrm{N}$ excretion in chickens has not been completely clarified yet. Probiotic bacteria can modify protein digestibility and the proteolytic breakdown of the undigested protein in the hind gut segments [19].

The results of studies evaluating biological agents to reduce ammonia emissions from poultry litter are contradictory [20-22] and the reason for the reduction in ammonia emissions has not been completely clarified either.

In our previous studies, it has been shown that no differences were observed in growth parameters among the treatment groups, although wheat bran had a beneficial effect on the caecal microbiota composition of broiler chickens. It can increase the ratio of butyric acid, decrease the $\mathrm{pH}$, and decrease the abundance of Campylobacter jejuni [8]. Feeding 
wheat bran also increases the growth of the bacteria responsible for mucosal regeneration, for example Akkermansia muciniphila [23].

In this study, the effect of using wheat bran, containing arabinoxylan, as a potential prebiotic and two existing probiotics were used to find out their effects on the N-composition of excreta, on the dynamics of in vitro ammonia emission, and on the amounts of ureolytic faecal bacteria.

\section{Materials and Methods}

A floor pen trial was carried out at the experimental farm of the Institute of Physiology and Nutrition, Hungarian University of Agriculture and Life Sciences (Georgikon Campus, Keszthely, Hungary). The animal experiment was approved by the Institutional Ethics Committee (Animal Welfare Committee, Georgikon Campus, Hungarian University of Agriculture and Life Sciences). One hundred and twenty-one-day-old Ross 308 broiler chickens were purchased from a commercial hatchery (Gallus Ltd. Devecser, Hungary) and placed into six floor pens, 20 chickens per pen (10 chickens per $\left.\mathrm{m}^{2}\right)$. Beside a corn and soybean-based control diet (C), a diet containing wheat bran was used (WB). Both diets were fed with or without probiotics. The probiotics used contained lactic acid-producing (LAB; Lactobacillus farciminis CNMA67-4R, Biacton, $5 \times 10^{9} \mathrm{CFU} / \mathrm{kg}$ ) and butyric acidproducing bacteria (BAB; Clostridium butyricum CBM 588; Miya-Gold, $2.5 \times 10^{9} \mathrm{CFU} / \mathrm{kg}$ ). The inclusion rate of both products was $0.5 \mathrm{~g} / \mathrm{kg}$. So, the dietary treatment combinations were: $\mathrm{C}, \mathrm{WB}, \mathrm{C}+\mathrm{LAB}, \mathrm{C}+\mathrm{BAB}, \mathrm{WB}+\mathrm{LAB}, \mathrm{WB}+\mathrm{BAB}$. The arrangement of the treatments was a $2 \times 3$ factorial design with two different diets $(C, W B)$ and three probiotic treatments $(\mathrm{LAB}, \mathrm{BAB}, \varnothing)$. Starter diets were fed from day 1 to 10 , grower diets from day 11 to 24 , and finisher diets from day 25 to 40 . Feed and drinking water were available ad libitum for the animals. The composition and nutrient content of diets are shown in Tables 1 and 2. As it can be seen in Table 1, the wheat bran content of the starter diets was 3\% and those of the grower and finisher diets were $6 \%$, respectively. Control diets contained slightly more soybean meal and the lower energy content of wheat bran was compensated by more oil incorporation. The crude protein and AMEn contents of the diets were close to each other. The crude fibre content of the WB diets was about $0.5 \%$ higher (Table 2). Computer controlled housing and climatic conditions were maintained during the trial according to the breeder's recommendations [24].

At day 37, eight chicks, with similar body weight, were transferred from each pen to individual balance cages, and excreta samples were collected, after 3 days adaptation period, on day 40 . In this phase, birds were fed the same finisher diets as before, in pens. At day 40 a minimum of $200 \mathrm{~g}$ excreta was collected from each animal and stored in a refrigerator at $-20^{\circ} \mathrm{C}$. Before the analyses, excreta were homogenized properly, then the $\mathrm{pH}$, dry matter content, total $\mathrm{N}$, ammonium- $\mathrm{N}\left(\mathrm{NH}_{4}{ }^{+}-\mathrm{N}\right)$ and uric acid- $\mathrm{N}$ contentsdetermined. The total $\mathrm{N}$ was determined according to the Kjeldahl method by the Foss-Kjeltec 8400 Analyzer Unit [25], the ammonium-N by the method of Peters [26], and the uric acid-N as described by Marquardt [27]. The sum of ammonium-N and uric acid-N was considered as urinary $\mathrm{N}$ content [28]. The in vitro ammonia emission measurement was carried out at two time points using the method of Santoso [13]. The ammonia concentration of the air was measured with Draeger equipment (model X-am 5600; Drägerwerk AG \& Co. KGaA, Lübeck, Germany). Samples were thawed $19 \mathrm{~h}$ before measurement. A total of $50 \mathrm{~g}$ homogenised excreta samples were placed into $1 \mathrm{~L}$ double-sealed containers. The samples were placed in the tanks at a temperature of $20^{\circ} \mathrm{C}$. Each container was equipped with a cover containing a hole to allow insertion of a gas measuring tube that was sealed inside with adhesive plaster. Measurements were taken two times: $1.5 \mathrm{~h}$ and then $4 \mathrm{~h}$ after entering the tank. The ammonia measurement range of the equipment's sensor was 0-300 ppm. The adhesive plaster was punctured, and $1000 \mathrm{~mL}$ of headspace air was collected from approximately $10 \mathrm{~cm}$ above the sample surface. After sampling, the tubes were sealed again. The concentration of $\mathrm{NH}_{3}$ was expressed as milligrams per liter. 
Table 1. Composition of experimental diets ( $\mathrm{g} / \mathrm{kg}$ as fed).

\begin{tabular}{|c|c|c|c|c|c|c|}
\hline & \multicolumn{2}{|c|}{$\begin{array}{c}\text { Starter } \\
\text { Day 1-10 }\end{array}$} & \multicolumn{2}{|c|}{$\begin{array}{c}\text { Grower } \\
\text { Day 11-24 }\end{array}$} & \multicolumn{2}{|c|}{$\begin{array}{c}\text { Finisher } \\
\text { Day 25-40 }\end{array}$} \\
\hline & $\mathrm{C}$ & WB & $\mathrm{C}$ & WB & $\mathrm{C}$ & WB \\
\hline Maize & 466 & 434 & 534 & 469 & 589 & 524 \\
\hline Wheat bran & 0 & 30 & 0 & 60 & 0 & 60 \\
\hline Extracted soybean meal & 338 & 333 & 361 & 352 & 310 & 300 \\
\hline Sunflower meal & 80 & 80 & 0 & 0 & 0 & 0 \\
\hline Sunflower oil & 63 & 70 & 62 & 76 & 60 & 74 \\
\hline Limestone & 19 & 19 & 15 & 15 & 15 & 15 \\
\hline $\mathrm{MCP}$ & 15 & 15 & 14 & 14 & 13 & 13 \\
\hline L-lysine & 5 & 5 & 2 & 2 & 2 & 2 \\
\hline DL-methionine & 4 & 4 & 3 & 3 & 3 & 3 \\
\hline L-threonine & 1 & 1 & 1 & 1 & 0 & 1 \\
\hline L-valine & 1 & 1 & 0 & 0 & 0 & 0 \\
\hline $\mathrm{NaCl}$ & 3 & 3 & 3 & 3 & 3 & 3 \\
\hline $\mathrm{NaHCO}_{3}$ & 1 & 1 & 1 & 1 & 1 & 1 \\
\hline Premix ${ }^{1}$ & 4 & 4 & 4 & 4 & 3.5 & 3.5 \\
\hline Phytase $^{2}$ & 0.1 & 0.1 & 0.1 & 0.1 & 0.1 & 0.1 \\
\hline NSP enzyme ${ }^{3}$ & 0.1 & 0.1 & 0.1 & 0.1 & 0.1 & 0.1 \\
\hline SUM & 1000 & 1000 & 1000 & 1000 & 1000 & 1000 \\
\hline \multicolumn{7}{|c|}{ 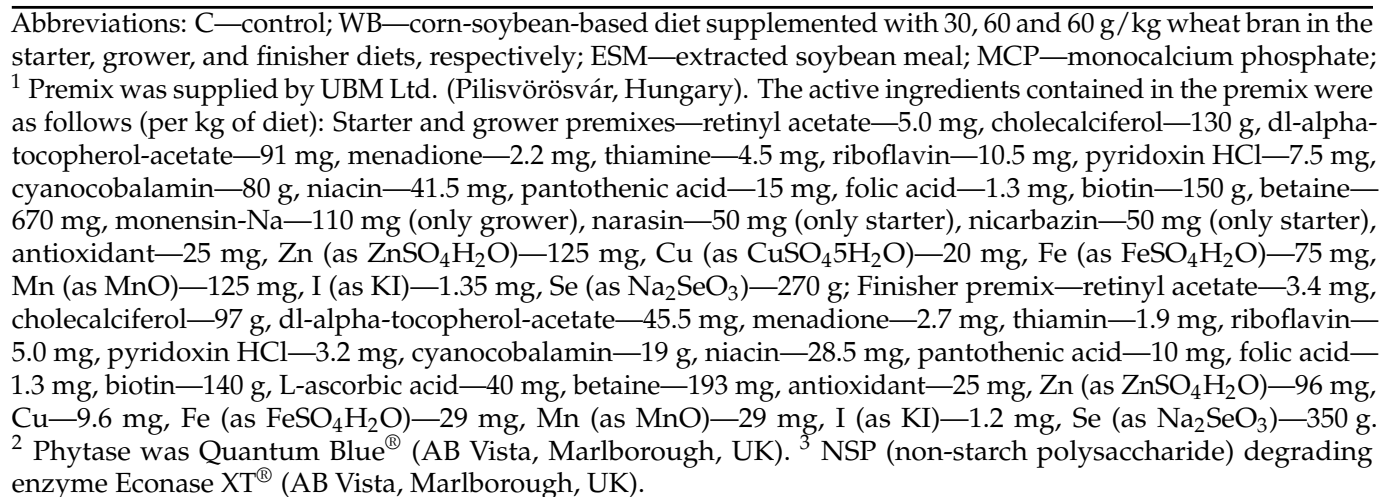 } \\
\hline
\end{tabular}

Table 2. Measured nutrient contents of the experimental diets ( $\mathrm{g} / \mathrm{kg}$ as fed).

\begin{tabular}{ccccccc}
\hline & \multicolumn{2}{c}{$\begin{array}{c}\text { Starter } \\
\text { Day 10 }\end{array}$} & \multicolumn{2}{c}{$\begin{array}{c}\text { Grower } \\
\text { Day 24 }\end{array}$} & \multicolumn{2}{c}{$\begin{array}{c}\text { Finisher } \\
\text { Day 40 }\end{array}$} \\
& C & WB & C & WB & C & WB \\
\hline AME $_{\text {n }}(\mathrm{MJ} / \mathrm{kg})$ & 12.1 & 12.2 & 13.1 & 13.0 & 13.0 & 13.1 \\
Dry matter & 88.8 & 89.0 & 88.5 & 88.8 & 88.2 & 88.8 \\
Crude protein & 22.9 & 23.0 & 20.7 & 21.2 & 18.8 & 19.1 \\
Crude fat & 8.3 & 9.2 & 9.1 & 10.1 & 8.9 & 10.0 \\
Crude fiber & 4.02 & 4.575 & 3.77 & 4.18 & 3.63 & 4.33 \\
Ash & 6.69 & 6.83 & 5.61 & 5.96 & 5.43 & 5.69 \\
Ca & 1.07 & 1.08 & 0.94 & 0.94 & 0.89 & 0.89 \\
P & 0.80 & 0.81 & 0.67 & 0.71 & 0.66 & 0.7 \\
Starch & 30.5 & 29.4 & 36.9 & 33.6 & 38.7 & 36.4 \\
\hline
\end{tabular}

The number of urease enzyme producing bacteria of excreta was estimated using the Most Probable Number (MPN) method based on the work of Fujita [29] using the Urea Broth Base (Scharlab). For each of the triplicate samples 10-fold serial dilutions $\left(10^{-1}-10^{-8}\right)$ were prepared in sterile phosphate buffered saline. The assay was performed using microplates. The microplates were incubated at room temperature for three days before being scored as positive or negative for urea hydrolysis. The color change due to the reaction was recorded with a fluorescence microplate reader (Perkin Elmer Enspire 2300, 
PerkinElmer, Inc; Waltham, MA, USA). Unfortunately, two groups of samples (WB+BAB, $\mathrm{WB}+\mathrm{LAB}$ ) failed due to experimental error and could not be evaluated.

Statistical evaluation was performed using SPSS 24.0 software. Two-way ANOVA was used in a $2 \times 3$ factorial arrangement. The model included effects of diet, probiotics, and the interaction between them. To understand the significant interactions between the main factors in the ammonia emission results, the treatment effects were also evaluated by one-way ANOVA. The experimental unit for the analysis of the fresh excreta was a cage with one individual bird. The Kruskal-Wallis test was used to evaluate the ratio of the fecal and urinary $\mathrm{N}$. The results on the ureolytic bacteria were analyzed by one-way ANOVA. The probability level of $p \leq 0.05$ was considered as statistically significant.

\section{Results}

Neither the diet composition nor the probiotic treatments affected the weight gain, feed intake, and fed conversion of chickens. The production traits results of the trial have been published earlier [30].

\subsection{Nitrogen Forms}

The dietary treatments did not significantly affect the amount of total $\mathrm{N}$ excretion. After feeding the control and wheat bran containing diets, statistically significant differences were found only in the $\mathrm{NH}^{+}{ }_{4}-\mathrm{N}$ content of the excreta $(p=0.024)$. WB treatment resulted in lower $\mathrm{NH}_{4}^{+}-\mathrm{N}$ concentrations (Table 3). LAB tended to increase $(p<0.099)$ and the BAB significantly increased $(p=0.012)$ the dry matter content compared with the control treatment. There was no significant interaction between the two main factors at any parameters.

Table 3. Composition and $\mathrm{pH}$ of excreta samples.

\begin{tabular}{|c|c|c|c|c|c|}
\hline Treatments & Total N & $\mathrm{NH}^{+}{ }_{4}-\mathrm{N}$ & Uric Acid-N & $\mathrm{pH}$ & Dry Matter \\
\hline \multicolumn{5}{|c|}{$\mathrm{mg} / \mathrm{g} \mathrm{DM}$} & $\%$ \\
\hline \multicolumn{6}{|c|}{ Probiotic effects } \\
\hline C & 50.076 & 4.864 & 17.531 & 6.322 & $21.454^{\mathrm{a}}$ \\
\hline LAB & 51.576 & 4.806 & 14.143 & 6.142 & $25.568^{a b}$ \\
\hline BAB & 50.468 & 4.065 & 15.407 & 6.278 & $27.321^{b}$ \\
\hline \multicolumn{6}{|c|}{ Diet effects } \\
\hline $\mathrm{C}$ & 50.624 & $5.172^{\mathrm{a}}$ & 16.836 & 6.258 & 24.315 \\
\hline WB & 50.75 & $4.000^{b}$ & 14.664 & 6.242 & 25.358 \\
\hline Pooled SEM & 2.744 & $\begin{array}{l}0.271 \\
\quad p \text {-val }\end{array}$ & 0.846 & 0.039 & 0.857 \\
\hline Probiotic & 0.979 & 0.273 & 0.224 & 0.168 & 0.012 \\
\hline Diet & 0.992 & 0.024 & 0.226 & 0.915 & 0.313 \\
\hline Probiotic $\times$ Diet & 0.827 & 0.128 & 0.875 & 0.170 & 0.412 \\
\hline
\end{tabular}

$\overline{\mathrm{a}, \mathrm{b}}$ means with different superscripts of the same column are significantly different.

Figure 1 shows that both probiotics increased the faecal and decreased the urinary $\mathrm{N}$ content of the excreta, but only the difference between LAB and control treatments was significant. Compared to the control group, the differences were $11 \%$ and $7 \%$ in the $\mathrm{LAB}$ and $\mathrm{BAB}$ treatments respectively. Feeding the wheat bran containing diets failed to modify the faecal and urinary $\mathrm{N}$ ratio. 


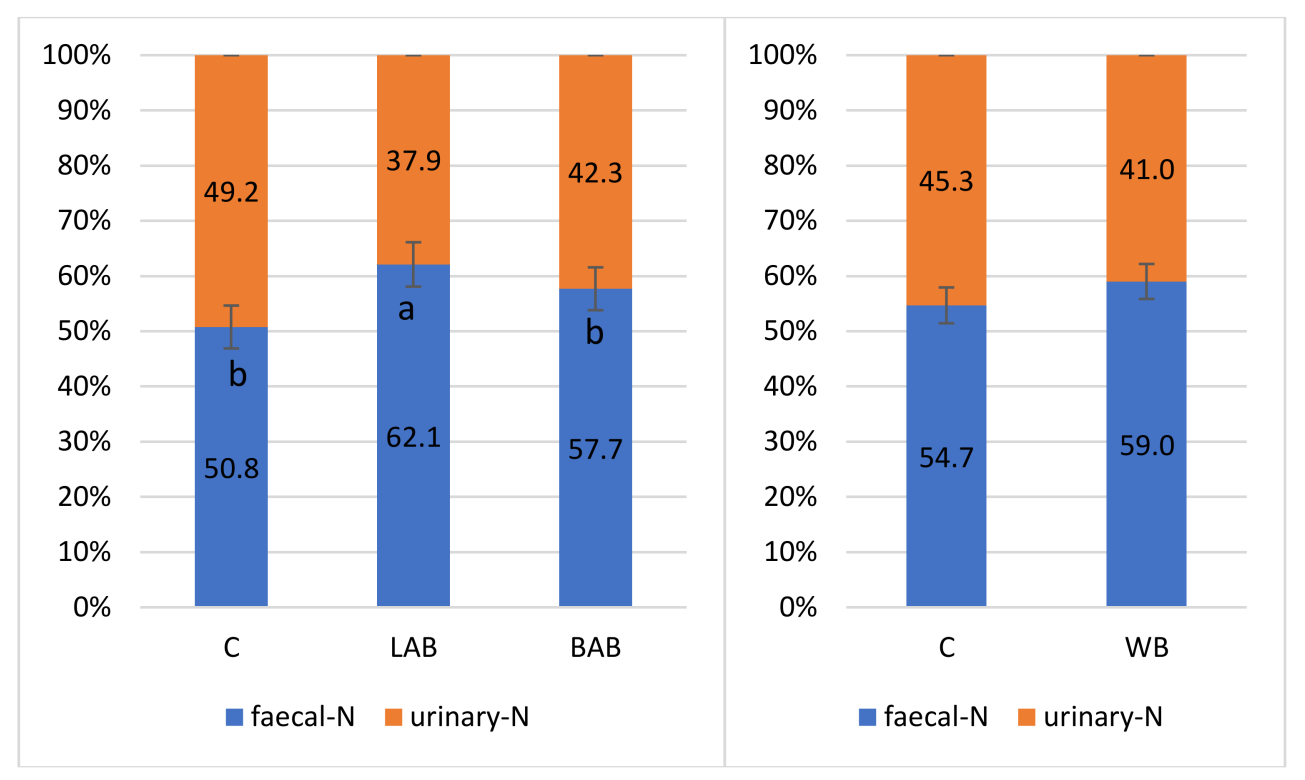

Figure 1. Treatment effects on the ratio of the faecal and urinary N. ${ }^{a, b}$ means with different superscripts are significantly different.

\section{2. $\mathrm{NH}_{3}$ Release from Excreta}

Dietary treatments did not influence $\mathrm{NH}_{3}$ release from the excreta significantly after $1.5 \mathrm{~h}$, but both the probiotics and wheat bran increased the volatilisation numerically (Table 4). After $4 \mathrm{~h}$, however, the wheat bran effect was already significant. At $1.5 \mathrm{~h}$ significant probiotic and wheat bran interaction was observed. The reason for this was that $\mathrm{LAB}$ increased the volatilisation, adding to the control diet, while the opposite was found when it was given to the $\mathrm{WB}$ diet.

Table 4. Treatment effects on the in vitro $\mathrm{NH}_{3}$ emission.



$\overline{\mathrm{a}, \mathrm{b}}$ means with different superscripts in the same column are significantly different. 


\subsection{Number of Ureolytic Bacteria in Excreta}

Although big differences were found between the averages, these differences were not significant because of the high standard error values (Figure 2). However, it can be seen that the number of urease producing bacteria in the WB group was about twice as high as in the control or $\mathrm{LAB}$ treatment groups. Treatment $\mathrm{C}+\mathrm{BAB}$ decreased this parameter.

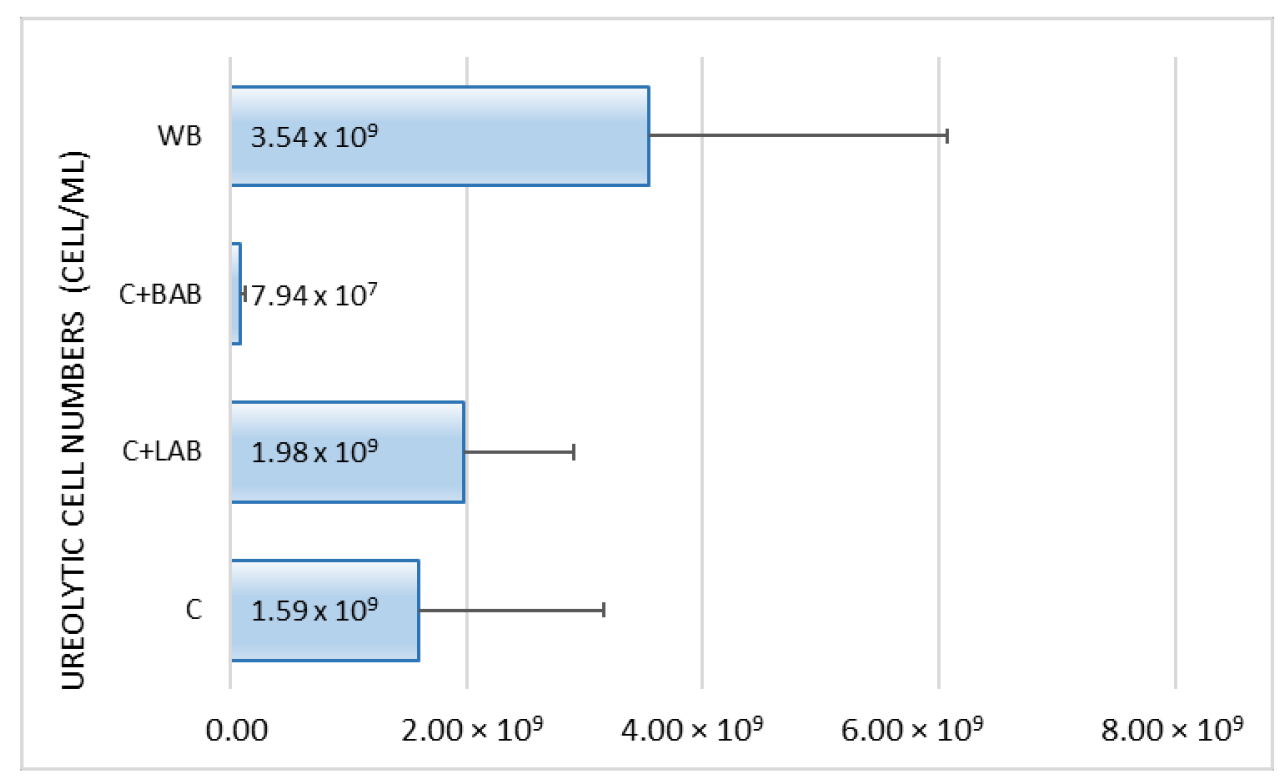

Figure 2. Number of ureolytic bacteria of the excreta.

\section{Discussion}

Several directives force the reduction of ammonia emissions from the agricultural sector (Common Agricultural Policy (CAP), the Nitrate Directive (91/676/EEC), and the Water Framework Directive (2000/60/EC)). The new NEC Directive ensures 2020 and 2030 emission reduction commitments for five main air pollutants, including $\mathrm{NH}_{3}$. The directive requires that the EU Member States draw up National Air Pollution Control Programmes. In Hungary, the application procedure is in progress, and nutrition of farm animals is a key factor in reducing ammonia emission.

Similarly, as in the findings of Jeong et al. [31] who fed B. subtilis supplemented diets to broiler chickens, no significant differences were observed in this trial in the uric acid-N, and total $\mathrm{N}$ content of excreta. However, in our study, the amount of $\mathrm{NH}^{+}{ }_{4}-\mathrm{N}$ in the excreta of chickens fed the bran containing diet decreased significantly. Santos et al. [32] obtained similar results for ammonium-N reduction, after feeding rice and soybean husks with broilers.

Probiotics increased the dry matter content of the excreta in our case. In a study with horses [33], a similar result was obtained regarding the dry matter content of faeces after probiotic treatment. Ammonia formation in barns is directly regulated by factors such as $\mathrm{pH}$, temperature, and litter moisture content [34]. An increase in the dry matter content of the excreta has a positive effect on litter quality, which can reduce the incidence of foot pad lesions, as well as greatly influence the release of ammonia [35]. In our trial probiotics decreased the ratio of urinary $\mathrm{N}$ of the excreta. The mechanism behind this result could be that both butyric and lactic acid decrease the $\mathrm{pH}$, and in this way inhibit the protease activity in the caeca. This can lead to increased incorporation of amino acids and ammonia by the microbiota, which leads to increased $\mathrm{N}$ content of the faeces and reduced renal $\mathrm{N}$-excretion [36-38]. Lower urinary $\mathrm{N}$ excretion could mean lower water intake and increased dry matter content of the excreta [39]. No such interaction has been published yet in the case of broiler chickens. 
In poultry, faeces and urine are excreted together in a mixture, making it difficult to separate faecal and urinary nitrogen. $\mathrm{O}^{\prime}$ dell et al. [27] found that the sum of uric acid and $\mathrm{NH}^{+}{ }_{4}-\mathrm{N}$ of the excreta gives approximately the total amount of urinary nitrogen in birds. Uric acid is more easily converted to ammonia than ammonium- $\mathrm{N}$. This is also affected by $\mathrm{pH}$, since in acidic $\mathrm{pH}$, most of the ammonia is converted to ammonium ions, which volatilize slowly [14]. Dietary fibre results increased SCFA production in the caeca, and this modified the $\mathrm{pH}$. This potential $\mathrm{pH}$ change in the caecal content did not affect the $\mathrm{pH}$ of excreta [40].

In our study, only treatment $\mathrm{LAB}$ increased the ratio of faecal $\mathrm{N}$ and decreased the ratio of urinary $\mathrm{N}$ in the excreta. Wheat bran in this trial failed to affect this parameter. It suggests that, contrary to pigs [14], the proportion of N-containing substances excreted via faeces and urine are more constant in poultry. Roberts et al. [41] showed that layer diets supplemented with DDGS (Distillers Dried Grains with Solubles), wheat middlings, or soybean hulls decreased ammonia emission from the manure but does not affect the ratio of urinary and faecal $\mathrm{N}$ of the excreta. In that experiment, the fibre sources were mostly structural. Since birds have relatively short large intestines and a quicker passage rate, it means a shorter period for bacterial fermentation. Because only the soluble and small fibre fractions can reach the caeca, the effects of caecal fermentation on the $\mathrm{N}$ composition of excreta did not change in that trial. As far as the authors know, it is the first result which proves that fermentable carbohydrates can also push the urinary $\mathrm{N}$ ratio towards faecal $\mathrm{N}$ in poultry species.

In contrast to previous studies [13,31,42,43], the type of probiotics used in our experiment did not have a statistically significant effect on the amount of ammonia released from the excreta. However, wheat bran supplementation resulted in significantly increased ammonia emission in vitro. Increased ammonia emissions due to wheat bran may have been caused by metabolic changes in the bacterial flora. In our previous study using the $16 \mathrm{~S}$ rRNA sequencing method, the diversity of the bacterial flora of the caecum did not change significantly under the influence of wheat bran [22,44], but several differences were observed at genus level. In the study of Vermeulen et al. [9], wheat bran supplementation significantly increased caecal microbiota abundance. Kieffer et al. [45] found that the metabolic change of the bacterial flora may provide more relevant information than the quantitative change in the microbiota. Stanley et al. [46] showed that the microbial composition of faeces in poultry was not the same as that of caecal microbiota. In the present study the xylan-oligosaccharides, the products of enzymatic breakdown of arabinoxylans of wheat can influence the amount and composition of the caecal microbiota and hence influence the urease activity of the manure.

Although the differences were not significant, the number of ureolytic bacterial flora in the excreta was two times higher in the WB group, which could have played a role in the in vitro $\mathrm{NH}_{3}$ emission. Many viable intestinal organisms such as Bacteroides, Bifidobacteria, Clostridia, Proteus spp., and Klebsiella spp. have urease activity. Dietary probiotics have been shown to suppress the growth of urease-producing bacteria [47], either by producing antimicrobials or by reducing the $\mathrm{pH}$, and subsequently reducing ammonia levels in chicken caeca [48]. According to Ahmed [49] the Bacillus amyloliquefaciens reduce ureasegenerating microbiota in the gastrointestinal lumen.

\section{Conclusions}

Pre- and probiotics are widely used to support gut health and the beneficial intestinal flora. Based on our results, these feed supplements can also modify the N-composition of excreta, which is currently a less researched area. From this study, it can be concluded that probiotics increase the dry matter content of the excreta, probably because of the lower urinary nitrogen excretion, and, therefore, the lower water intake of the chickens. The addition of wheat bran to the diets did not affect the amount of $\mathrm{N}$ excreted via faeces and urine. This result proves that, in contrast to mammals, fermentable fibres in poultry have only limited effect on the proportion of the excreted bacterial protein. In poultry, this 
mechanism differs from the microbial processes in pigs, because in poultry species only a small proportion of undigested fibres and oligosaccharides enter the caeca, and the content of it represents a relatively small proportion of the whole excreta. On the other hand, based on these results, the soluble fibre fraction of the feed can influence the amount of $\mathrm{NH}_{3}$ released from the excreta and can change the dynamics of the emission.

Author Contributions: Conceptualization, N.S. and K.D.; methodology, N.S., G.C. and L.W. formal analysis, N.S. and K.D.; investigation, N.S.; L.P.; V.F.; P.S. (Patrik Strifler); P.S. (Petra Stankovics); I.A.K. and K.D.; data curation, L.W.; I.A.K. and G.C.; writing-original draft preparation, N.S. and K.D. writing-review and editing, N.S.; P.S. (Petra Stankovics) and K.D.; visualization, N.S.; supervision, K.D.; project administration, K.D. and N.S.; funding acquisition, K.D. All authors have read and agreed to the published version of the manuscript.

Funding: This research was supported by the Hungarian Ministry of Agriculture (AKGF/43/2021).

Institutional Review Board Statement: The animal experiment was approved by the Institutional Ethics Committee (Animal Welfare Committee, Georgikon Campus, Hungarian University of Agriculture and Life Sciences) under the license number MÁB-9/2019.

Informed Consent Statement: Not applicable.

Data Availability Statement: All data generated or analyzed during this study are included in this published article.

Acknowledgments: This work was prepared with the professional support of the Doctoral Student Scholarship Program of the Cooperative Doctoral Program of the Ministry for Innovation and Technology financed from the National Research, Development, and Innovation fund, and this research was supported by the ÚNKP-20-3-II New National Excellence Program of the Ministry for Innovation and Technology, from the Source of the National Research, Development and Innovation Fund.

Conflicts of Interest: All authors declare no conflict of interest.

\section{References}

1. Knapp, C.W.; Dolfing, J.; Ehlert, P.A.; Graham, D.W. Evidence of Increasing Antibiotic Resistance Gene Abundances in Archived Soils since 1940. Environ. Sci. Technol. 2010, 44, 580-587. [CrossRef] [PubMed]

2. Jjemba, P.K. The Potential Impact of Veterinary and Human Therapeutic Agents in Manure and Biosolids on Plants Grown on Arable Land: A Review. Agric. Ecosyst. Environ. 2002, 93, 267-278. [CrossRef]

3. Terényi, M. Az Antibiotikum Felhasználás Jogi Szabályozása; Állatgyógyászati Termékek Igazgatósága: Hajdúszoboszló, Hungary, 2016.

4. Anadón, A.; Rosa Martínez-Larrañaga, M.; Aranzazu Martínez, M. Probiotics for Animal Nutrition in the European Union. Regulation and Safety Assessment. Regul. Toxicol. Pharmacol. 2006, 45, 91-95. [CrossRef] [PubMed]

5. Andersson, H.; Asp, N.-G.; Bruce, Å.; Roos, S.; Wadström, T.; Wold, A.E. Health Effects of Probiotics and Prebiotics A Literature Review on Human Studies. Näringsforskning 2001, 45, 58-75. [CrossRef]

6. Schneeman, B.O. Gastrointestinal Physiology and Functions. Br. J. Nutr. 2002, 88, S159-S163. [CrossRef]

7. Canani, R.B.; Costanzo, M.D.; Leone, L.; Pedata, M.; Meli, R.; Calignano, A. Potential Beneficial Effects of Butyrate in Intestinal and Extraintestinal Diseases. World J. Gastroenterol. 2011, 17, 1519-1528. [CrossRef] [PubMed]

8. Molnár, A.; Hess, C.; Pál, L.; Wágner, L.; Awad, W.A.; Husvéth, F.; Hess, M.; Dublecz, K. Composition of Diet Modifies Colonization Dynamics of Campylobacter Jejuni in Broiler Chickens. J. Appl. Microbiol. 2015, 118, 245-254. [CrossRef] [PubMed]

9. Vermeulen, K.; Verspreet, J.; Courtin, C.M.; Haesebrouck, F.; Baeyen, S.; Haegeman, A.; Ducatelle, R.; Van Immerseel, F. Reducedparticle-Size Wheat Bran Is Efficiently Colonized by a Lactic Acid-Producing Community and Reduces Levels of Enterobacteriaceae in the Cecal Microbiota of Broilers. Appl. Environ. Microbiol. 2018, 84, 1343-1361. [CrossRef] [PubMed]

10. Raninen, K.; Lappi, J.; Mykkänen, H.; Poutanen, K. Dietary Fiber Type Reflects Physiological Functionality: Comparison of Grain Fiber, Inulin, and Polydextrose. Nutr. Rev. 2011, 69, 9-21. [CrossRef]

11. Zhang, R.; Ishibashi, K.; Day, D.L. Experimental Study of Microbial Decomposition in Liquid Swine Manure, and Generation Rates of Ammonia. In Proceedings of the Livestock Waste Management Conference, American Society of Agricultural Engineers, St. Joseph, MI, USA, 23-26 April 1991.

12. Varel, V.H.; Wells, J.E.; Miller, D.N. Combination of a Urease Inhibitor and a Plant Essential Oil to Control Coliform Bacteria, Odour Production and Ammonia Loss from Cattle Waste. J. Appl. Microbiol. 2007, 102, 472-477. [CrossRef]

13. Santoso, U.; Ohtani, S.; Tanaka, K.; Sakaida, M. Dried Bacillus Subtilis Culture Reduced Ammonia Gas Release in Poultry House. Asian-Australas. J. Anim. Sci. 1999, 12, 806-809. [CrossRef] 
14. Aarnink, A.J.A.; Verstegen, M.W.A. Nutrition, Key Factor to Reduce Environmental Load from Pig Production. Livest. Sci. 2007, 109, 194-203. [CrossRef]

15. Singh, A.K.; Kim, W.K. Effects of Dietary Fiber on Nutrients Utilization and Gut Health of Poultry: A Review of Challenges and Opportunities. Animals 2021, 11, 181. [CrossRef] [PubMed]

16. Nahm, K.H. Evaluation of the Nitrogen Content in Poultry Manure. Worlds Poult. Sci. J. 2003, 59, 77-88. [CrossRef]

17. Yusrizal; Chen, T.C. Effect of Adding Chicory Fructans in Feed on Fecal and Intestinal Microflora and Excreta Volatile Ammonia. Int. J. Poult. Sci. 2003, 2, 188-194. [CrossRef]

18. Awad, W.A.; Böhm, J.; Razzazi-Fazeli, E.; Ghareeb, K.; Zentek, J. Effect of Addition of a Probiotic Microorganism to Broiler Diets Contaminated with Deoxynivalenol on Performance and Histological Alterations of Intestinal Villi of Broiler Chickens. Poult. Sci. 2006, 85, 974-979. [CrossRef] [PubMed]

19. Wang, J.; Ji, H. Influence of Probiotics on Dietary Protein Digestion and Utilization in the Gastrointestinal Tract. Curr. Prot. Pep. Sci. 2018, 20, 125-131. [CrossRef]

20. DeLaune, P.B.; Moore, P.A.; Daniel, T.C.; Lemunyon, J.L. Effect of Chemical and Microbial Amendments on Ammonia Volatilization from Composting Poultry Litter. J. Environ. Qual. 2004, 33, 728-734. [CrossRef] [PubMed]

21. Shah, S.B.; Baird, C.L.; Rice, J.M. Effect of a Metabolic Stimulant on Ammonia Volatilization from Broiler Litter. J. Appl. Poult. Res. 2007, 16, 240-247. [CrossRef]

22. Cook, K.L.; Rothrock, M.J.; Eiteman, M.A.; Lovanh, N.; Sistani, K. Evaluation of Nitrogen Retention and Microbial Populations in Poultry Litter Treated with Chemical, Biological or Adsorbent Amendments. J. Environ. Manag. 2011, 92, 1760-1776. [CrossRef]

23. Such, N.; Farkas, V.; Koltay, I.; Rawash, M.A.; Dublecz, K.; Molnár, A. Wheat Bran Supplementation Increases the Abundance of Akkermansia Muciniphila Whereas Single Strain Probiotic Clostridium Butyricum Fails to Influence Caecal Microflora Composition of Broiler Chickens. In Proceedings of the 18, BOKU-Symposium Animal Nutrion, Vienna, Austria, 30 April 2019; pp. 189-192.

24. Aviagen. Roos Broiler Management Handbook; Aviagen: Huntsville, AL, USA, 2018.

25. Magyar Szabványügyi Testület. Animal Feeding Stuffs. Determination of Nitrogen Content and Calculation of Crude Protein Content. Part 2: Block Digestion and Steam Distillation Method (ISO 5983-2:2009); Magyar Szabványügyi Testület: Budapest, Hungary, 2009.

26. Peters, B.J. Recommended Methods for Manure Analysis; A3769; University of Wisconsin, Cooperative Extension Publishing: Madison, WI, USA, 2003.

27. Marquardt, R.R.; Ward, A.T.; Campbell, L.D. A Rapid High-Performance Liquid Chromatographic Method for the Quantitation of Uric Acid in Excreta and Tissue Samples. Poult. Sci. 1983, 62, 2099-2105. [CrossRef]

28. O'dell, B.L.; Woods, W.D.; Laerdal, O.A.; Jeffay, A.M.; Savage, J.E. Distribution of the Major Nitrogenous Compounds and Amino Acids in Chicken Urine. Poult. Sci. 1960, 39, 426-432. [CrossRef]

29. Fujita, Y.; Taylor, J.L.; Wendt, L.M.; Reed, D.W.; Smith, R.W. Evaluating the Potential of Native Ureolytic Microbes To Remediate a 90Sr Contaminated Environment. Environ. Sci. Technol. 2010, 44, 7652-7658. [CrossRef] [PubMed]

30. Such, N.; Molnár, A.; Farkas, V.; Pál, L.; Husvéth, F.; Koltay, I.; Rawash, M.; Mezőlaki, Á.; Dublecz, K. Feeding Two Single Strain Probiotic Bacteria and Wheat Bran Failed to Modify the Production Traits but Altered Some Gut Characteristics in Broiler Chickens. J. Cent. Eur. Agric. 2020, 21, 499-507. [CrossRef]

31. Jeong, J.S.; Kim, I.H. Effect of Bacillus Subtilis C-3102 Spores as a Probiotic Feed Supplement on Growth Performance, Noxious Gas Emission, and Intestinal Microflora in Broilers. Poult. Sci. 2014, 93, 3097-3103. [CrossRef]

32. DOS Santos, S.; Laosutthipong, C.; Yamauchi, K.E.; Thongwittaya, N.; Sittiya, J. Effects of Dietary Fiber on Growth Performance, Fecal Ammonia Nitrogen and Gastrointestinal Tract pH in Broilers from 1 to 21 Days of Age. Walailak Procedia 2019, 1, IC4IR-73.

33. Such, N.; Koltay, I.A.; Ujj, Z.; Bányai, A.; Bartos, A. Egy Probiotikus Kiegészítő Hatása a Takarmány Táplálóanyagainak Látszólagos Emészthetőségére Lovakkal Végzett Kísérletben. Állattenyésztés és Tak. 2017, 66, 196-205.

34. Elliott, H.A.; Collins, N.E. Factors Affecting Ammonia Release in Broiler Houses. Am. Soc. Agric. Eng. Trans. 1982, 25, 413-418. [CrossRef]

35. Brouček, J.; Čermák, B. Emission of Harmful Gases from Poultry Farms and Possibilities of Their Reduction. Ekol. Bratisl. 2015, 34, 89-100. [CrossRef]

36. Cloetens, L.; De Preter, V.; Swennen, K.; Broekaert, W.F.; Courtin, C.M.; Delcour, J.A.; Rutgeerts, P.; Verbeke, K. Dose-Response Effect of Arabinoxylooligosaccharides on Gastrointestinal Motility and on Colonic Bacterial Metabolism in Healthy Volunteers. J. Am. Coll. Nutr. 2013, 27, 512-518. [CrossRef] [PubMed]

37. Wutzke, K.D.; Lotz, M.; Zipprich, C. The Effect of Pre- and Probiotics on the Colonic Ammonia Metabolism in Humans as Measured by Lactose-[15N2]Ureide. Eur. J. Clin. Nutr. 2010, 64, 1215-1221. [CrossRef] [PubMed]

38. Macfarlane, G.T.; Cummings, J.H. The colonic flora, fermentation and large bowel digestive function. In The Large Intestine: Physiology, Pathophysiology and Disease; Raven Press: New York, NY, USA, 1991; pp. 51-92.

39. Dirk Van Der Klis, J.; De Lange, L. Water Intake of Poultry. In Proceedings of the 19th European Symposium on Poultry Nutrition, Potsdam, Germany, 26-29 August 2013.

40. Wathes, C.M. Aerial Emissions from Poultry Production. Worlds Poult. Sci. J. 1998, 54, 241-251. [CrossRef]

41. Roberts, S.A.; Xin, H.; Kerr, B.J.; Russell, J.R.; Bregendahl, K. Effects of Dietary Fiber and Reduced Crude Protein on Ammonia Emission from Laying-Hen Manure. Poult. Sci. 2007, 86, 1625-1632. [CrossRef] [PubMed] 
42. Hassan, M.R.; Ryu, K.-S. Naturally Derived Probiotic Supplementation Effects on Physiological Properties and Manure Gas Emission of Broiler Chickens. J. Agric. Life Sci. 2012, 46, 119-127.

43. Yoon, C.; Park, J.H.; Nam, Y.M. Effect of Feeding Multiple Probiotics on Performance and Fecal Noxious Gas Emission in Broiler Chicks -Korean Journal of Poultry Science I Korea Science. Korean Soc. Poult. Sci. 2004, 31, 229-235. [CrossRef]

44. Molnár, A.; Such, N.; Farkas, V.; Pál, L.; Menyhárt, L.; Wágner, L.; Husvéth, F.; Dublecz, K. Effects of Wheat Bran and Clostridium Butyricum Supplementation on Cecal Microbiota, Short-Chain Fatty Acid Concentration, $\mathrm{PH}$ and Histomorphometry in Broiler Chickens. Animals 2020, 10, 2230. [CrossRef] [PubMed]

45. Kieffer, D.A.; Martin, R.J.; Adams, S.H. Impact of Dietary Fibers on Nutrient Management and Detoxification Organs: Gut, Liver, and Kidneys. Adv. Nutr. 2016, 7, 1111-1121. [CrossRef]

46. Stanley, D.; Geier, M.S.; Chen, H.; Hughes, R.J.; Moore, R.J. Comparison of Fecal and Cecal Microbiotas Reveals Qualitative Similarities but Quantitative Differences. BMC Microbiol. 2015, 15, 51. [CrossRef]

47. Yeo, J.; Kim, K. Il Effect of Feeding Diets Containing an Antibiotic, a Probiotic, or Yucca Extract on Growth and Intestinal Urease Activity in Broiler Chicks. Poult. Sci. 1997, 76, 381-385. [CrossRef]

48. Endo, T.; Nakano, M.; Shimizu, S.; Fukusima, M.; Miyoshi, S. Effects of a Probiotic on the Lipid Metabolism of Cocks Fed on a Cholesterol-Enriched Diet. Biosci. Biotechnol. Biochem. 1999, 63, 1569-1575. [CrossRef]

49. Ahmed, S.T.; Islam, M.M.; Mun, H.S.; Sim, H.J.; Kim, Y.J.; Yang, C.J. Effects of Bacillus Amyloliquefaciens as a Probiotic Strain on Growth Performance, Cecal Microflora, and Fecal Noxious Gas Emissions of Broiler Chickens. Poult. Sci. 2014, 93, $1963-1971$. [CrossRef] [PubMed] 